\title{
Measuring Consumer Behavior in Banking: Scale Development and Validation
}

\author{
Zaid Ahmad Ansari ${ }^{1}$ \\ ${ }^{1}$ College of Business and Economics, Qassim University, Buraydah, Qassim, Saudi Arabia \\ Correspondence: Dr. Zaid Ahmad Ansari, College of Business and Economics, Buraydah, Qassim, Saudi Arabia. \\ E-mail: drzaidansari@gmail.com
}

Received: August 2, 2019

Accepted: September 11, 2019

Online Published: October 28, 2019

doi:10.5539/ijbm.v14n11p263

URL: https://doi.org/10.5539/ijbm.v14n11p263

\begin{abstract}
The purpose of this paper is to construct a valid and reliable scale measuring consumer behavior with respect to banking industry. The study has highlighted that consumer behavior in banking industry can be measured by four factors banking services, consumer trust, employee behavior and the online services. These four factors have been measured using 26 items. The scale developed has shown high reliability, discriminant validity and has remained consistent across different samples. The findings have revealed that banking services is the most important determinant of consumer behavior followed by consumer trust, employee behavior and online services.
\end{abstract}

Keywords: banking, consumer behavior, consumer trust, employee behavior

\section{Introduction}

With the moderate recovery in the oil production levels and with the increase in the public spending World Bank estimates that Saudi Arabian economy is expected to expand in 2018 with a $1.8 \%$ increase in GDP. The year 2017 was a year of recovery and consolidation for banking sector in Saudi Arabia. The surge in interbank offered rate in 2017 had an overall positive influence on the profitability and an overall positive impact on the margins which was reflected in the ROEs and ROAs in 2017 (KPMG, 2017). In order to keep up the growth trajectory for the 2030 vision the financial sector of Saudi Arabia is committed to increasing the total size of financial assets to GDP ratio to reach $201 \%$ by 2020 from 192\% registered in 2016.

Banking sector organizations in Saudi Arabia need to become heavily focused on the customer because of the recent regulations aimed at enhancing transparency, demographic changes and the rise of fintech. At the same time, it's very important that banks respond to these changes in a strategic manner. This all has made consumer retention very difficult and the ability to cross sell products to existing customers critically important in determining profitability. The only way to respond to these changes is to better understand the customer in an attempt to not only anticipate, but also to determine consumer behavior (Beckett et al., 2000).

However, there is a dearth of studies which have studies the various factors which determine consumer behavior in the context of a developing country like Saudi Arabia. Researchers in this study have focused on Saudi Arabia which has a diverse immigrant population, sharia based legal and political system which makes this study an exclusive case point. There have been very few studies which have studies the acceptance of online banking like Al-Somali et al., (2009) but there are hardly any studies which have studies the overall consumer behavior in banking sector. Therefore, the purpose of this paper is to develop a reliable and valid scale to measure consumer behavior in banking sector. Second, to study the relative importance of those factors.

\section{Background and Review of Literatures}

Consumer behavior is an activity of decision making, where an individual is engaged in evaluating, using, and disposal of goods and services. Advent of technology and increased use of internet forced the business into digital age affecting every aspect of routine life from acquisition of knowledge to analysis of products and services (Kim \& Lennon, 2008). Banking sector is no exception here. Traditional banking services commonly provided in developed countries are still at budding stage in the markets of Middle East, which creates chaos among consumers, regarding quality of services. In this situation customers usually search for better alternatives (Kassim, \& Souiden, 2007). It is a well-known fact that consumer is the "boss" indicating that company cannot 
exist without consumers. Means no consumer no sales, which can lead to bankruptcy of a company, therefore consumer behavior has become a burning issue in today's competitive world. Thus studying and understanding the consumer behavior has become a herculean task for companies of modern world, especially in banking sector, its analysis is complex and it is difficult to analyze and understand (Fejza, Livoreka, \& Bajrami, 2017). Chaker (2015) suggested that service design of banking sector is different from that of manufacturing, as services are intangible, warranty or repair processes are not as important as recovery or reimbursement processes" (pp. 25 $34)$.

The growing body of literature reveals most of the discussion related to consumer behavior in banking sector is related its components. The literature revealed researchers possesses diverse opinions regarding the consumer behavior in banking sector. One of the important component discussed in the literature of banking consumer behavior is banking services (Fejza et al., 2017). Highlighting the importance of services, Saiz, and Pilorge (2010) suggested that banks should provide the services according to the requirements of customers, if they want to meet the challenge of retaining customers and restoring public confidence. On similar lines, Fejza et al. (2017) suggested bank is distinguished by its clients, so if a bank needs to be inventive it should provide new services or systematically modify the existing in order to provide something innovative in the market. Highlighting the importance of services Anneli Jarvinen, (2014) stressed that unsatisfactory banking services may have a negative effect on the relationship between bank and customers. Likewise, Flavian, Torres, and Guinaliu, (2004) suggested in order to compete organizations may exploit new resources of competitive advantage to offer distinguished services to their customers. On similar lines, various researchers suggest that services are intangible entity that may enhance the propensity of the customers and may result in well-articulated customer evaluation criteria (Kassim, \& Souiden, 2007; Keaveney, 1995; Zeithaml, Parasuraman, \& Berry, 1993; and Lovelock, 1991). Referring banking industry as a service industry Sarker, Bose, and Khan, (2012) argued customer attitude has become a buzzword in banking sector and suggested banking sector should provide high quality services to its customers at priority basis that will help to gain the positive attitude of the customers.

Another important factor that emerges from the literature is consumer/customer trust, Blomqvist

(1997) reported as a construct its roots can be traced from different schools like, marketing research, social psychology, economics etc. and each discipline possesses diverse viewpoint on it (Yee \& Yeung, 2010). Castelfranchi and Falcone, (2010) reported trust as a situation and context-specific issue, understanding of which is based on beneficial exchanges done on mutual basis in marketplaces (Shim, Serido, \& Tang, 2013). In the banking industry trust is considered a variable of utmost importance (Kantsberger \& Kunz, 2010) as its deficiency indicates a serious problem in banking sector and it acts as an indication for bank managers to reduce the perceived risk in banking services (Anneli Jarvinen, 2014). Saiz, and Pilorge (2010) contend that, fall in amount of trust lays a profound effect on the banking industry, further Saiz, and Pilorge stated that decline in the consumer trust effects customer relationship and forces the customer to explore more suitable services elsewhere thereby diluting the customer relationship. Highlighting its importance Robinson and Jackson, (2001) and Putnam, (2000) stated that trust acts as a vital component for democracy, social integration and national wealth and generates social capital. Shim, Serido, and Tang, (2013) see social trust as powerful economic that measures the health of a society.

One of the important factor related to consumer behavior in banking industry is employee behavior, employee behavior is a significant factor in service sector because it is immediately integrated by customers while forming overall judgment (Lemmink \& Mattsson, 2002). Browning (2006) referred employee behavior to interaction between service provider and consumer. It is identified as sum total of gestures (voice, attitude and movements) performed by an employee while serving customers (Tsaur, Chang, \& Wu, 2004). In service sector an employee is supposed to deal with emotional expression of customers (Rafaeli, 1989), less skilled employees may not be able to handle the situation when image of organization is at stake (Lemmink \& Mattsson, 2002). Law, Wang, and Hui (2010) viewed employee behavior as universal contribution of performance towards an organization. Relating employee behavior with human resource management Liao, Toya, Lepak, and Hong, (2009) reported that service behavior for consumer satisfaction is managed by the human resource management with the management of knowledge, skill, abilities and performance of the employees. On similar lines, researchers Humphery, Ehrich, Kelly, Sandall, Redfern, Morgan, and Guest (2003) and Tsaur and Lin (2004) found that employee behavior effects service quality perceptions of customers through human resource management.

One of the other widely discussed components include online facilities/e-facilities, which is a blend of internet, computer technology, and conventional banking (Sikdar, Kumar, \& Makkad, 2015). Yaseen, and El Qirem, (2018) reported that internet and digital technologies bought drastically changes in banking sector around the globe. Similarly, Servon, and Kaestner, (2008) reported that in recent years, proliferation of e-technologies along with 
variety of e-products in banking sector escalated the adoption of online facilities among customers. The intense use of online technologies facilitated the banking industry to deliver electronic services effectively (Gordon, Pires, \& Stanton 2008; Dajani and Yaseen, 2016). Chai, Tan, and Goh, (2016) argued that advent of globalization escalated diversity in customer demands and technological innovations lays a great impact on management of banking industry of retaining and attracting potential customers and investors. Due to rapid developments in technological innovations various studies, Sikdar et al. (2015); Suzanne Harrison, Peter Onyia, \& Tagg, (2014) consider online banking facility as an innovative channel for distribution of financial services. In-order to keep pace with the global trends and practices, banking industry realized that upgrading in the technology has become obligatory to achieve their goals (Chandrasekhar \& Sonar, 2008). To stay in competition, maintain pace, and enhance their performance banking industry is constantly investing in technological equipment's, human resources, and training of employees, in-order to address the diverse customer demands for efficient, consistent, and quick services (Sangeetha, and Mahalingam, 2011; Sivabrovornvatana, Siengthai, Krairit, \& Himangshu, 2005).

\section{Scale Development}

In this study, the renowned scale development procedure given by Churchill (1979) and Hinkin (1995) further amplified by Bentler and Bonnet (1980), Anderson and Gerbing (1982), Bhat and Bashir (2017) was adopted. The graphical representation of scale development procedure (Garg, Rahman, \& Qureshi, 2014) is shown in figure 1 below.

\section{ITEM GENERATION \& SELECTION PHASE}

\section{SCALE REFINEMENT PHASE}

\section{SCALE VALIDATION PHASE}
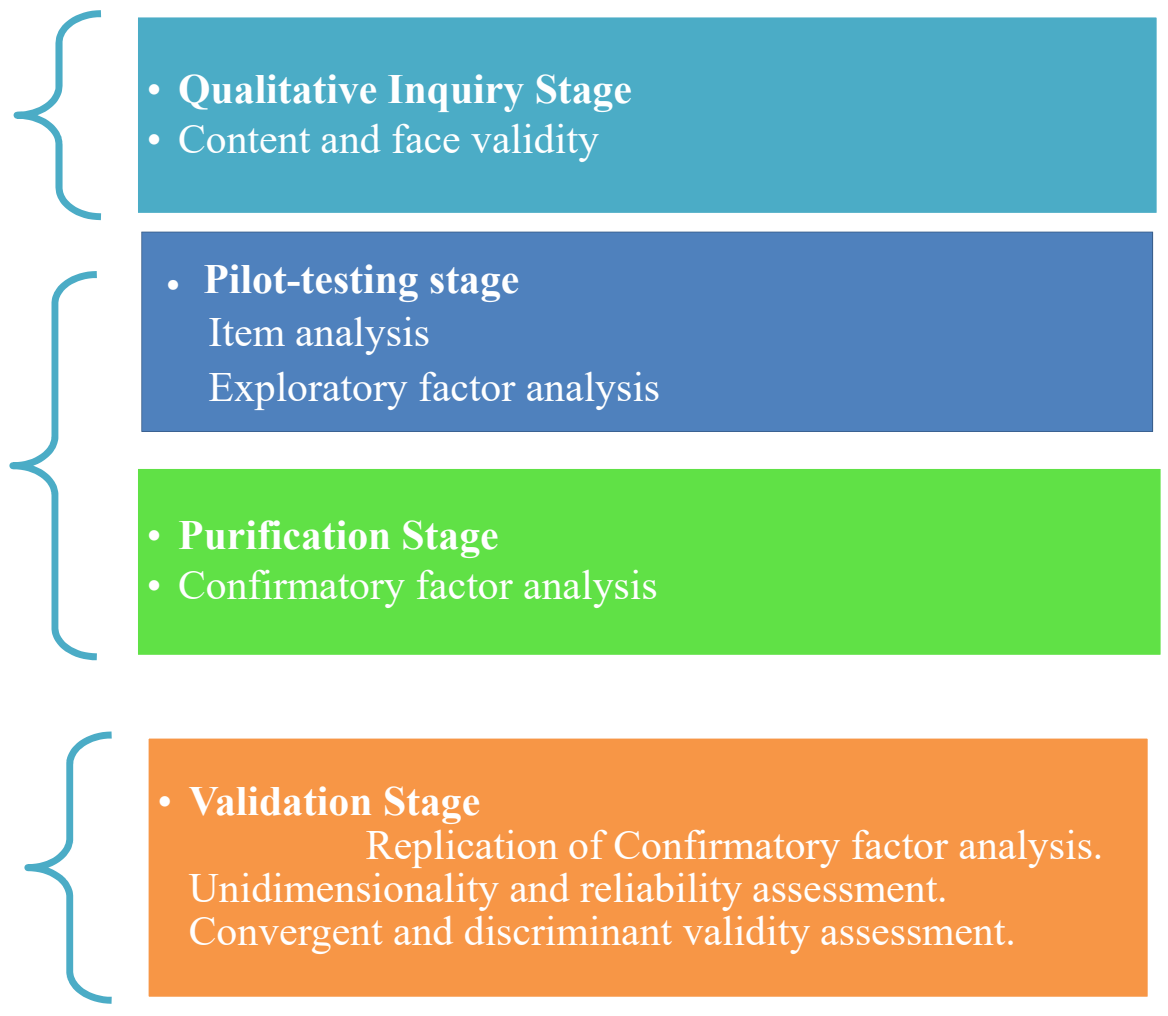

Figure 1. Procedure of scale development

\section{Phase I: Item generation and selection.}

Researcher carried out an extensive literature survey to generate the specific items which covers the proposed factors of consumer behavior in banking sector. Researcher employed deductive method to generate the items as per recommendations of Hinkin (1995). Researchers initially framed an item pool comprising of 70 statements measuring consumer behavior in banking sector. A five point Likert scale was used to rate every individual item where 5 means "strongly agree" and 1 means "strongly disagree".

In lateral stage, a panel of 12 experts (professors/bank managers) thoroughly analyzed the item pool and deleted 8 overlapping items. In next stage, the panel was requested to retain the clearly worded items and remove the 
ambiguous and misinterpreting items (Babin et al., 1994), panel agreed and deleted 5 items. Subsequently, the experts were requested to rate each item on three categories as proposed by Lin and Hsieh (2011), on three categories i.e. "clearly representative", "somewhat representative" and "not representative". Initial screening based on expert feedback resulted in the deletion of 5 more items. The scale was revised and again evaluated on several occasions and 4 items were deleted, finally an item pool comprising of 48 items was once more reviewed and this time experts, suggested use of familiar wording.

Further, 40 management graduates take part in the study of consumer behavior in banking sector, they were instructed to assess the degree to which 48 items on consumer behavior in banking sector describe their experience, using a five point Likert sale where 1 - strongly disagree and 5- strongly agree, which is in line with suggestions of Brakus et al. (2009). Only those items were retained having mean value greater than 3 and standard deviation less than 2, as suggested by Garg, et al. (2014), accordingly 2 more items were deleted and final set contains 46 items.

\section{Phase II: Scale Refinement and Purification.}

According to figure 1 present phase covers pilot-testing and purification of the instrument. For the purpose of pilot testing, the questionnaire covering 46 items, was divided into two sections $1^{\text {st }}$ section deals with the demographics of the instrument and $2^{\text {nd }}$ section covers the 46 items on consumer behavior in banking sector.

For preliminary refinement of items, data was gathered on new sample of respondents, similar to Brakus et al. (2009), Lin and Hsieh (2011), Froehle and Roth (2004), Bhat and Beri (2016a), Bhat and Beri (2016b) and Garg et al. (2014). A sample of 200 respondents was collected which is in line with Garg et al. (2014), Bhat and Bashir (2017). For complete refinement of instrument, recommendations of Churchill (1979) item analysis, EFA, and CFA were adopted, which are as follows.

a) Item analysis: According to Churchill (1979) computation of Cronbach's alpha is the first and foremost step in purification stage of instrument. Cronbach's alpha for all factors i.e. 46 of consumer behavior in banking was calculated with the help of SPSS 21, the value of coefficient ranged from .683 to .714. But according to Nunnally (1978) the minimum value of alpha must be .70. Therefore, to improve the value of alpha researchers analyzed item to item correlation and items having correlation below threshold value were deleted. The process was iterated several times and 6 items were deleted. The final value of Cronbach's alpha ranged from .781 to .820 .

b) Exploratory Factor Analysis: Next subsequent process after item analysis is computation of EFA on the remaining items of the scale. Exploratory Factor Analysis was applied using SPSS 21. Costello and Osborne, (2005) suggested EFA determine the uncertain links between the latent and observed variables, principal component analysis along with varimax was performed to extract the factor. As per the recommendation of Karatepe, Yavas, and Babakus, (2005) and Hair et al. (1998), the minimum criteria for retaining the items is factor loading $>.50$, and communalities $<.40$. The calculated value of Kaiser-Meyer-Olkin statistics is .966 which is higher than the threshold value of 0.60 suggested by Tabachnick and Fidell (1996). The EFA results revealed that consumer behavior scale in banking sector decomposed into 4 factors covering 33 items with Eigen values $>1$ (Kaiser 1960) and accounted for $77.24 \%$ of total variance explained Table 1. 
Table 1. Exploratory factor analysis

\begin{tabular}{|c|c|c|c|c|c|}
\hline \multicolumn{6}{|c|}{ Rotated Component Matrix } \\
\hline \multirow[t]{2}{*}{ S. No } & \multirow[t]{2}{*}{ Statement } & \multicolumn{4}{|c|}{ Component } \\
\hline & & 1 & 2 & 3 & 4 \\
\hline CB 1 & Overall service quality of my bank is good & .833 & & & \\
\hline CB 3 & My bank maintains customer service at high priority & .813 & & & \\
\hline CB 4 & It's quite easy to get the desired service at my bank & .809 & & & \\
\hline CB 5 & The Waiting time to receive a service in my bank is low & .793 & & & \\
\hline $\mathrm{CB} 2$ & My bank has convenient Working/Banking hours & .791 & & & \\
\hline CB 6 & My Bank usually provides more customer oriented services & .786 & & & \\
\hline CB 14 & The ATM facilities of my bank are readily available & .785 & & & \\
\hline CB 8 & Mobile banking facilities of my bank are good & .778 & & & \\
\hline CB 7 & My bank has almost all the financing schemes & .774 & & & \\
\hline CB 13 & My bank keeps different loans facilities readily available to its customers & .751 & & & \\
\hline CB 16 & My bank employees have high level of Professionalism & & .800 & & \\
\hline CB 17 & Overall behavior and cooperation of the employees of my bank is good & & .786 & & \\
\hline CB 19 & Security of information is updated at my bank & & .777 & & \\
\hline CB 18 & My bank has educated employees & & .766 & & \\
\hline CB 21 & My bank employees have high Willingness & & .757 & & \\
\hline CB 24 & My bank employees show high level of Friendliness & & .737 & & \\
\hline CB 22 & My bank maintains a very high reputation in market & & .732 & & \\
\hline CB 25 & My bank always hire efficient employees & & .726 & & \\
\hline CB 26 & My bank employees have high level of Pleasantness & & .725 & & \\
\hline $\mathrm{CB} 27$ & My bank employees have positive Attitude & & .723 & & \\
\hline CB 31 & My bank employees shows courteous approach while dealing with customers & & & .719 & \\
\hline $\mathrm{CB} 32$ & My bank employees maintain a congenial work atmosphere during working hours & & & .709 & \\
\hline CB 34 & My bank employees show high level of Kindness while dealing with customers & & & .706 & \\
\hline CB 33 & My bank employees remains Smiling and cheerful during working hours & & & .604 & \\
\hline CB 36 & My bank employees reflects high level of Politeness & & & .593 & \\
\hline CB 38 & All the customers are being treated equally by my bank & & & .582 & \\
\hline CB 28 & My bank employees show high willingness to help customers & & & .575 & \\
\hline CB 37 & My bank employees have high levels of Professionalism & & & .564 & \\
\hline CB 39 & My bank provides clear and understandable interaction with an online bank & & & & .758 \\
\hline $\mathrm{CB} 40$ & Information about benefits of using online banking is readily available in my bank & & & & .618 \\
\hline $\mathrm{CB} 41$ & Online banking enhances the effectiveness of utilizing banking services & & & & .570 \\
\hline CB 42 & Online banking enables to utilize banking services more quickly & & & & .630 \\
\hline CB 43 & My bank provides flexibility of using online banking & & & & .594 \\
\hline
\end{tabular}

c) Confirmatory Factor Analysis: After calculating EFA nest step in scale purification phase is to calculate CFA. According to Joreskog and Sorbom, (2004) CFA is a special case of Structure Equational Modelling (SEM) which is known as linear structural relationship model. In order to test the stability of 4 factors covering 33 items, another new sample of 300 respondents was collected conveniently. The CFA model was studied by applying AMOS 19.0. The initial model indices appear as CMIN/DF $=3.148, \mathrm{RMR}=.076, \mathrm{GFI}=.893, \mathrm{AGFI}=.892$, CFI $=.912$, RMSEA $=0.77$. The results revealed that some of the model indices are below threshold value. Like value of CMIN/DF is above threshold value of 3, GFI and AGFI are acceptable but are below value of 9. In order to improve the results of model fit investigator reduced some of the items. Investigator used modification indices, factor loadings, subjective judgment and suggestions of 3 human resources professors as criteria to remove the items. This complete process results in the deletion of 6 items. The final CFA model with 27 items produces a good fit, having indices as $\mathrm{CMIN} / \mathrm{DF}=2.348, \mathrm{RMR}=.066, \mathrm{GFI}=.903, \mathrm{AGFI}=.912, \mathrm{CFI}=.952$, RMSEA $=0.67$ figure 2 . 


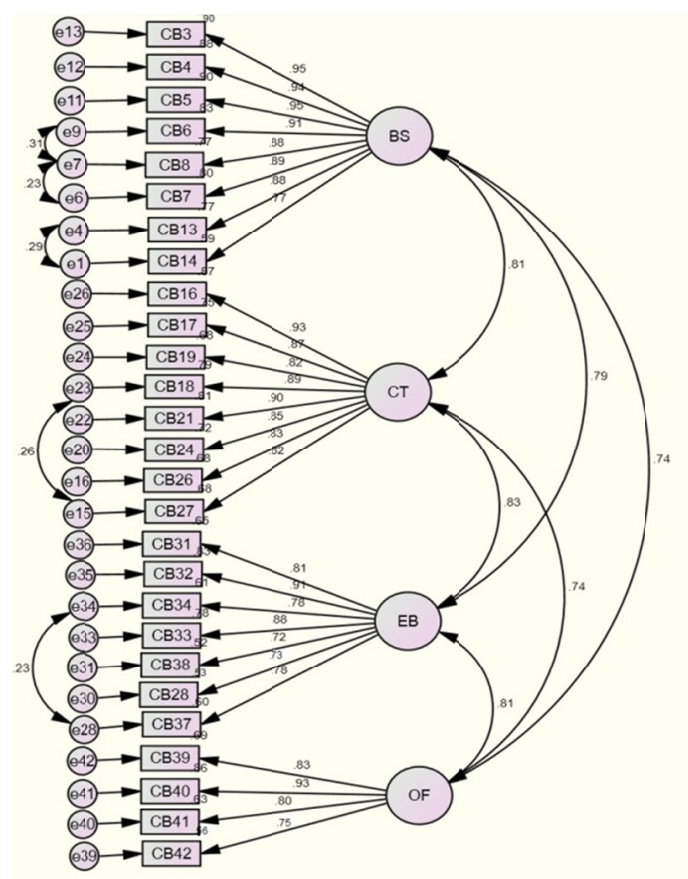

Figure 2. Cofirmatory factor analysis

d) Replication of Confirmatory Factor Analysis: researcher Keith (2005) consider second order factor model as complex, constrained and parsimonious as compared to the first order factor model. The calculation of second order factor model resulted in the deletion of 1 more item and overall model fit of second order was CMIN/DF = $2.41, \mathrm{RMR}=.069, \mathrm{GFI}=.899, \mathrm{AGFI}=.901, \mathrm{CFI}=.912, \mathrm{RMSEA}=0.69$. Figure 3 .

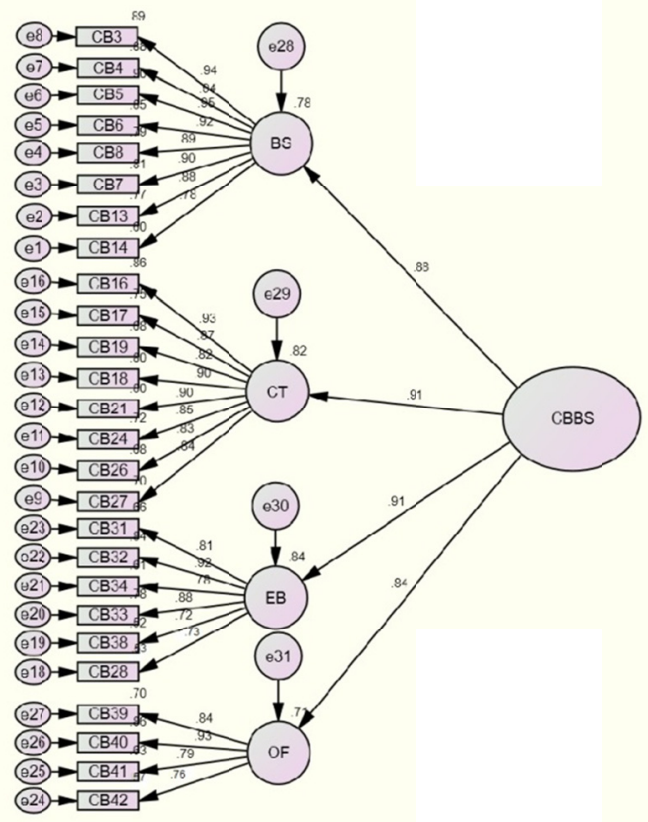

Figure 3. Second order factor model 


\section{Phase III: Scale validation.}

e) Unidimensionality and reliability: The analysis highlighted that each item of the present scale is related with one and only one fundamental construct, confirming Unidimensionality of the measures (Gerbing and Anderson 1988). Further the results also highlighted that the values of Cronbach's alpha ranges from .85 to .79 and composite reliability ranges from 0.89 to 0.97 , confirming high internal consistency and good construct reliability (Nunnally and Bernstein 1994) table no 2.

Table 2. Factor loading, composite reliability and average variance extracted values (AVE) Model 1

\begin{tabular}{|c|c|c|c|}
\hline Domains & Factor loading & Composite reliability & Average variance extracted \\
\hline & .95 & & \\
\hline & .94 & & \\
\hline & .95 & & \\
\hline \multirow[t]{8}{*}{ Banking Services } & .91 & 0.97 & 0.80 \\
\hline & .88 & & \\
\hline & .89 & & \\
\hline & .88 & & \\
\hline & .77 & & \\
\hline & .93 & & \\
\hline & .87 & & \\
\hline & .82 & & \\
\hline \multirow[t]{8}{*}{ Consumer Trust } & .89 & 0.95 & 0.74 \\
\hline & .90 & & \\
\hline & .85 & & \\
\hline & .83 & & \\
\hline & .82 & & \\
\hline & .81 & & \\
\hline & .91 & & \\
\hline & .71 & & \\
\hline \multirow[t]{4}{*}{ Employee Behavior } & .88 & 0.92 & 0.63 \\
\hline & .72 & & \\
\hline & .73 & & \\
\hline & .83 & & \\
\hline \multirow[t]{3}{*}{ Online facilities. } & .93 & 0.89 & 0.67 \\
\hline & .80 & & \\
\hline & .71 & & \\
\hline
\end{tabular}

f) Construct and discriminant validity: According to Hair et al. (1998) construct validity can be established by calculating average variance extracted of all the factors of model. The results highlighted factors measuring consumer behavior in banking sector exhibits an average variance extracted score .60 (Table 2). Also researchers Fornell and Larcker (1981) argued that average variance score of .50 and greater provides sufficient evidence of construct validity.

For calculating the discriminant validity of present scale the shared variance between different measures was compared with the AVEs of the individual measures (Bove et al. 2009). The results depict that calculated shared variance between the measures was less than the AVE of individual measures. Further the discriminant validity was also calculated by comparing the squared correlations between the constructs with AVE value of each construct (Fornell and Larcker, 1981) Table 3. 
Table 3. Comparison between square of correlations of different factors and AVE of individual factors

\begin{tabular}{|c|c|c|c|}
\hline Factors & $\begin{array}{l}\text { Correlation } \\
\text { Coefficient } \\
\end{array}$ & $\begin{array}{ll}\text { Square } & \text { of } \\
\text { Correlation } & \\
\end{array}$ & AVE \\
\hline $\mathrm{OF}<->\mathrm{EB}$ & .77 & .59 & $.80(\mathrm{OF})$ \\
\hline $\mathrm{OF}<->\mathrm{CT}$ & .76 & .58 & $.74(\mathrm{~EB})$ \\
\hline $\mathrm{OF}<->\mathrm{BS}$ & .74 & .55 & $.63(\mathrm{CT})$ \\
\hline $\mathrm{EB}<->\mathrm{CT}$ & .78 & .60 & .67 (BS) \\
\hline $\mathrm{EB}<->\mathrm{BS}$ & .79 & .62 & \\
\hline $\mathrm{CT}<->\mathrm{BS}$ & .79 & .62 & \\
\hline
\end{tabular}

\section{Discussion}

This study has adopted highly valid and reliable scale development procedures by Churchill (1979) and Hinkin (1995). Researchers have developed a 26 item scale (See Annexure) covering 4 factors measuring the banking consumer behavior. The context of the study is limited to the Saudi Arabia. The findings revealed that consumer behavior can be measured as a four factor construct composing of banking services, consumer trust, employee behavior and online facilities. The scale has shown high internal consistency across different samples. The study has passed reliability tests like construct and discriminant validity. Out of the four factors which measure banking consumer behavior "Banking services" emerged out to be the most important factor. The second most dominant factor is the consumer trust. Then the employee behavior and online facilities are the other two most moderately important factors. Prior studies have also highlighted the significance of these factors.

\subsection{Managerial Implications}

The study contributes to the existing literature on consumer behavior by constructing a valid and reliable scale to measure consumer behavior with respect to banking sector in the Saudi Arabia. This study has highlighted that consumer behavior in banking sector can be measured by four factors like banking services, consumer trust, employee behavior and online facilities provided by the bank. The findings of this study has several implications for the marketers of banking services.

First, the study has highlighted that one of the important determinants of consumer buying behavior is the banking services provided by the banks. Marketers and policy makers need to keep in mind that they always provide the best of the services at the competitive prices because if the services are not up to the mark retention of the customers would become extremely difficult. Second, the study will help in measuring consumer trust towards banking services offered by the banks. This will help companies to access the level of trust which consumers have with the respective banks. Marketers can also take the pre and post scores to access discrepancies after implementing some solutions which they feel will improve consumer trust towards the services offered by the banks.

Third, the study has highlighted the importance of employee behavior in developing a good customer perfection about the banks. Good employee behavior will not only help in increasing the customer satisfaction levels but also in increasing the consumer trust. Fourth, the study has highlighted that even in developing economy like Saudi Arabia it's very important to have a good online presence. Therefore, it's extremely important that every banks should have all the online touch points which will make the life of the customer easy.

\subsection{Limitations \& Scope for Future Research}

This study has some limitations which demand attention. The data collection was confined to Saudi Arabia only which hamper the generalization of the results. Therefore, future research should be conducted across other GCC countries to access the differences in the results. Further a comparative study can be conducted to access the differences in consumer behavior with respect to developed and developing countries. Second, the scale has been tailored for banking sector only. Therefore, future research can be conducted across other sectors like E-commerce to determine differences if any. Third, the study has focused on both the Islamic and as well as non-Islamic banks. Future researchers can study whether there is any differences in consumer behavior across Islamic and conventional banks.

\section{References}

Al-Somali, S. A., Gholami, R., \& Clegg, B. (2009). An investigation into the acceptance of online banking in Saudi Arabia. Technovation, 29(2), 130-141. https://doi.org/10.1016/j.technovation.2008.07.004

Anderson, J. C., \& Gerbing, D. W. (1982). Some methods for respectifying measurement models to obtain 
unidimensional construct measurement. Journal of Marketing Research, 19(4), 453-461.

Anneli Järvinen, R. (2014). Consumer trust in banking relationships in Europe. International Journal of Bank Marketing, 32(6), 551-566.

Babin, B. J., Darden, W. R., \& Griffin, M. (1994). Work and/or fun: measuring hedonic and utilitarian shopping value. Journal of Consumer Research, 20, 644-656.

Beckett, A., Hewer, P., \& Howcroft, B. (2000). An exposition of consumer behaviour in the financial services industry. International Journal of Bank Marketing, 18(1), 15-26.

Bentler, P. M., \& Bonnet, D. G. (1980). Significance tests and goodness of fit in the analysis of covariance structures. Psychological Bulletin, 88(3), 588-606. http://dx.doi.org/10.1037/h0020412

Bhat, S. A., \& Bashir, M. (2018). Measuring ICT orientation: Scale development \& validation. Education and Information Technologies, 23(3), 1123-1143.

Bhat, S. A., \& Beri, A. (2016a). Development and validation of Teachers Perceived Job Performance Scale (TPJP) in higher education. Man in India, 96(4), 935-944.

Bhat, S. A., \& Beri, A. (2016b). ICT orientation: development and validation of ICTOR scale for teachers. Man in India, 96(9), 3123-3134.

Blomqvist, K. (1997). The many faces of trust. Scandinavian Journal of Management, 13(3), 271-286. http://dx.doi.org/10.1016/S0956-5221(97)84644-1

Bove, L. L., Pervan, S. J., Beatty, S. E., \& Shiu, E. (2009). Service worker role in encouraging customer organizational citizenship behaviors. Journal of Business Research, 62(7), 698-705.

Brakus, J. J., Schmitt, B. H., \& Zarantonello, L. (2009). Brand experience: what is it? How is it measured? Does it affect loyalty? Journal of Marketing, 73(3), 52-68.

Browning, V. (2006). The relationship between HRM practices and service behavior in South African service organizations. The International Journal of Human Resource Management, 17(7), 1321-1338.

Castelfranchi, C., \& Falcone, R. (2010). Trust Theory. A Socio-cognitive and Computational Model. John Wiley and Sons Ltd., Chichester.

Chai, B. B. H., Tan, P. S., \& Goh, T. S. (2016). Banking services that influence the bank performance. Procedia-Social and Behavioral Sciences, 224, 401-407. https://doi.org/10.22440/wjae.3.2.2

Chaker, M. N. (2015). Consumers' perceptions of banks country of origin in the UAE. Eurasian Journal of Economics and Finance, 3(3), 25-34.

Churchill Jr., G. A. (1979). A paradigm for developing better measures of marketing constructs. Journal of Marketing Research, 16(1), 64-73. https://doi.org/10.2307/3150876

Costello, A. B., \& Osborne, J. W. (2005). Best practices in exploratory factor analysis: Four recommendations for getting the most from your analysis. Practical assessment, research \& evaluation, 10(7), 1-9.

Dajani, D., \& Yaseen, S. G. (2016). The applicability of technology acceptance models in the Arab business setting. Journal of Business and Retail Management Research, 10(3).

Fejza, V., Livoreka, R., \& Bajrami, H. (2017). Analyzing Consumer Behavior in Banking Sector of Kosovo. Eurasian Journal of Business and Management, 5(4), 33-48.

Flavian, C., Torres, E., \& Guinaliu, M. (2004). Corporate image measurement. International Journal of Bank Marketing, 22(5), 366-384.

Fornell, C., \& Larcker, D. F. (1981). Evaluating structural equation models with unobservable variables and measurement error. Journal of Marketing Research, 18(1), 39-50.

Froehle, C. M., \& Roth, A. V. (2004). New measurement scales for evaluating perceptions of the technology-mediated customer service experience. Journal of Operations Management, 22(1), 1-21.

Garg, R., Rahman, Z., \& Qureshi, M. N. (2014). Measuring customer experience in banks: scale development and validation. Journal of Modelling in Management, 9(1), 87-117.

Gerbing, D. W., \& Anderson, J. C. (1988). An updated paradigm for scale development incorporating unidimensionality and its assessment. Journal of Marketing Research, 25, 186-192.

Gordon, T. L., Pires, G. D., \& Stanton, J. (2008). The Relationship Marketing Orientation of Hong Kong 
Financial Services Industry Managers and its Link to Business Performance. Journal of Financial Services Marketing, 13(3), 193-203. https://doi.org/10.1509/jimk.13.1.36.58538

Hair, J. F., Anderson, R. E., Tatham, R. L., \& Black, W. C. (1998). Multivariate data analysis (5th ed.). PrenticeHall, Englewood Cliffs.

Hinkin, T. R. (1995). A brief tutorial on the development of measures for use in survey questionnaires. Organizational Research Methods, 1(1), 104-121.

Humphery, C., Ehrich, K., Kelly, B., Sandall, J., Redfern, S., Morgan., M., \& Guest, D. (2003). Human resource policies and continuity of care. Journal of Health Organization and Management, 17(2), 102-121. https://doi.org/10.1108/14777260310476159

Joreskog, K. G., \& Sorbom, D. (2004). LISREL 8.7. Chicago: Scientific Software International Inc.

Kaiser, H. F. (1960). The application of electronic computers to factor analysis. Educational and Psychological Measurement, 20, 141-151. https://doi.org/10.1177/001316446002000116

Kantsberger, R., \& Kunz, W. H. (2010). Consumer trust in service companies: A multiple mediating analysis. Managing Service Quality, 20(1), 4-25. https://doi.org/10.1108/09604521011011603

Karatepe, O. M., Yavas, U., \& Babakus, E. (2005). Measuring service quality of banks: scale development and validation. Journal of Retailing and Consumer Services, 12(5), 373-383.

Kassim, N. M., \& Souiden, N. (2007). Customer retention measurement in the UAE banking sector. Journal of Financial Services Marketing, 11(3), 217-228.

Keaveney, S. M. (1995). Customer switching behavior in service industries: An exploratory study. Journal of Marketing, 59, 71-82.

Kim, M., \& Lennon, S. (2008). The effects of visual and verbal information on attitudes and purchase intentions in Internet shopping. Psychology \& Marketing, 25, 146-178.

Law, K. S., Wang, H., \& Hui, C. (2010). Currencies of exchange and global LMX: how they affect employee task performance. Asia pacific Journal of Management, 27(4), 625-646.

Lemmink, J., \& Mattsson, J. (2002). Employee behavior, feelings of warmth and customer perception in service encounters. International Journal of Retail \& Distribution Management, 30(1), 18-33. https://doi.org/10.1108/09590550210415239

Liao, H., Toya, K., Lepak, D. P., \& Hong, Y. (2009). Do they see eye to eye? Management and employee perspective of high-performance work systems and influence process on service quality. Journal of Applied Psychology, 94(2), 371-391.

Lin, J. C., \& Hsieh, P. (2011). Assessing the self-service technology encounters: development and validation of SSTQUAL scale. Journal of Retailing, 85(2), 194-206.

Lovelock, C. H. (1991). Services Marketing (3rd ed.). Upper Saddler River, NJ.: Prentice-Hall Inc.

Nunnally, J. C. (1978). Psychometric theory. New York: McGraw-Hill.

Nunnally, J. C., \& Bernstein, I. H. (1994). Psychometric Theory (3rd ed.). New York, NY.: McGraw-Hill.

Putnam, R. D. (2001). Bowling alone: The collapse and revival of American community. New York: Simon and Schuster.

Rafaeli, A. (1989). When clerks meet customers: A test of variables related to emotional expressions on the job. Journal of applied psychology, 74(3), 385-393.

Robinson, R. V., \& Jackson, E. F. (2001). Is trust in others declining in America? An age-period-cohort analysis. Social Science Research, 30(1), 117-145. http://dx.doi.org/10.1006/ssre.2000.0692

Saiz, B., \& Pilorge, P. (2010). Understanding customer behavior in retail banking: The impact of the credit crisis across Europe. Earnest and Young. Retrieved from http://www.ey.com

Sangeetha, J., \& Mahalingam, S. (2011). Service quality models in banking: A review. International Journal of Islamic and Middle Eastern Finance and Management, 4(1), 83-103. https://doi.org/10.1108/17538391111122221

Sarker, S., Bose, T., \& Khan, A. (2012). Attitudes of customers towards the financial institutions-A comparison between private commercial banks and nationalized commercial banks in Bangladesh with implications of Fishbein model. International Journal of Managing Value and Supply Chains, 3(4), 13. 
Servon, L. J., \& Kaestner, R. (2008). Consumer financial literacy and the impact of online banking on the financial behavior of lower-income bank customers. Journal of Consumer Affairs, 42(2), 271-305. https://doi.org/10.1111/j.1745-6606.2008.00108.x

Shim, S., Serido, J., \& Tang, C. (2013). After the global financial crash: individual factors differentiating young adult consumers' trust in banks and financial institutions. Journal of Retailing and Consumer Services, 20(1), 26-33. https://doi.org/10.1016/j.jretconser.2012.10.001

Sikdar, P., Kumar, A., \& Makkad, M. (2015). Online Banking Adoption a Factor Validation and Satisfaction Causation Study in the Context of Indian Banking Customers. International Journal of Bank Marketing, 33(6), 760-785. https://doi.org/10.1108/IJBM-11-2014-0161

Sivabrovornvatana, N., Siengthai, S., Krairit, D., \& Himangshu, P. (2005). Technology usage, quality management system, and service quality in Thailand. International Journal of Health Care Quality Assurance, 18(6), 413-423. https://doi.org/10.1108/09526860510619417

Suzanne Harrison, T., Peter Onyia, O., \& K. Tagg, S. (2014). Towards a universal model of internet banking adoption: initial conceptualization. International Journal of Bank Marketing, 32(7), 647-687. https://doi.org/10.1108/IJBM-06-2013-0056

Tabachnick, B. G., \& Fidell, L. S. (1996). Using multivariate statistics (3rd ed.). New York: Harper Collins College.

Tsaur, S. H., \& Lin, Y. C. (2004). Promoting service quality in tourist hotels: The role of HRM practices and service behavior. Tourism Management, 25(4). 471-481. https://doi.org/10.1016/S0261-5177(03)00117-1

Tsaur, S. H., Chang, H. M., \& Wu, C. S. (2004). Promoting service quality with employee empowerment in tourist hotels: The role of service behavior. Asia Pacific Management Review, 9(3), 435-461.

Yaseen, S. G., \& El Qirem, I. A. (2018). Intention to use e-banking services in the Jordanian commercial banks. International Journal of Bank Marketing, 36(3), 557-571.

Yee, W. M., \& Yeung, R. M. W. (2010). An empirical examination of the role of trust in consumer and supplier relationship of little direct contact: a structural equation modelling approach. Journal of International Food \& Agribusiness Marketing, 22(1-2), 143-163. https://doi.org/10.1080/08974430903373003

Zeithaml, V. A., Parasuraman, A., \& Berry, L. L. (1993). The nature and determinants of customer expectations of service, Journal of Academy of Marketing Science, 21(1), 1-12. http://dx.doi.org/10.1177/0092070393211001

\section{Annexure I}

Consumer Behavior in Banking Sector: Scale Development and Validation

Please fill in the following information:

NAME:

GENDER:Male $\square$ Female $\square$

QUALIFICATION:

TYPE OF BANK: Public INSTRUCTIONS

Note: Following statements are regarding Consumer Behavior in Banking Sector. Please read each statement carefully and mark your response on five alternatives provided viz., Strongly Agree=SA, Agree=A, Neutral=N, Disagree=D \& Strongly Disagree=SD. Put a tick on alternative which is close to your view. It is requested to yourself please answer all statements. Please answer freely as your responses will be kept confidential and will used for research purpose only. 


\begin{tabular}{|c|c|c|c|c|c|c|c|}
\hline $\mathrm{Sr}$ & Statements & SA & $\mathbf{A}$ & $\mathbf{N}$ & DA & SD & Score \\
\hline & Banking services & & & & & & \\
\hline 1 & My banks maintain customer services at high priority. & & & & & & \\
\hline 2 & It's quite Easy to get the desired service at my bank & & & & & & \\
\hline 3 & The Waiting time to receive a service in my bank is low & & & & & & \\
\hline 4 & My Bank usually provides more customer oriented services. & & & & & & \\
\hline 5 & The ATM facilities of my bank are readily available & & & & & & \\
\hline 6 & Mobile banking facilities of my bank are good & & & & & & \\
\hline 7 & My bank has almost all the financing schemes & & & & & & \\
\hline \multirow[t]{2}{*}{8} & My bank keeps different loans facilities readily available to its customers & & & & & & \\
\hline & Consumer Trust & & & & & & \\
\hline 1 & My bank employees have high level of Professionalism & & & & & & \\
\hline 2 & Overall behavior and cooperation of the employees of my bank is good & & & & & & \\
\hline 3 & Security of information is updated at my bank & & & & & & \\
\hline 4 & My bank has educated employees & & & & & & \\
\hline 5 & My bank employees have high Willingness & & & & & & \\
\hline 6 & My bank employees show high level of Friendliness & & & & & & \\
\hline 7 & My bank employees have high level of Pleasantness & & & & & & \\
\hline \multirow[t]{2}{*}{8} & My bank employees have positive Attitude & & & & & & \\
\hline & Employee Behavior & & & & & & \\
\hline 1 & My bank employees show courteous approach while dealing with customers & & & & & & \\
\hline 2 & My bank employees maintain a congenial work atmosphere during working hours & & & & & & \\
\hline 3 & My bank employees show high level of Kindness while dealing with customers & & & & & & \\
\hline 4 & My bank employees remain Smiling and cheerful during working hours & & & & & & \\
\hline 5 & All the customers are being treated equally by my bank. & & & & & & \\
\hline \multirow[t]{2}{*}{6} & My bank employees have high levels of Professionalism & & & & & & \\
\hline & Online Facilities & & & & & & \\
\hline 1 & My bank provides clear and understandable interaction with an online bank & & & & & & \\
\hline 2 & Information about benefits of using online banking is readily available in my bank & & & & & & \\
\hline 3 & Online banking enhances the effectiveness of utilizing banking services & & & & & & \\
\hline \multirow[t]{2}{*}{4} & Online banking enables to utilize banking services more quickly & & & & & & \\
\hline & Total Score & & & & & & \\
\hline
\end{tabular}

\section{Copyrights}

Copyright for this article is retained by the author(s), with first publication rights granted to the journal.

This is an open-access article distributed under the terms and conditions of the Creative Commons Attribution license (http://creativecommons.org/licenses/by/4.0/). 